\title{
Microbial aggregates within tissues infect a diversity of corals throughout the Indo-Pacific
}

\author{
Thierry M. Work ${ }^{1,2, *}$, Greta S. Aeby ${ }^{2}$ \\ ${ }^{1}$ US Geological Survey, National Wildlife Health Center, Honolulu Field Station, PO Box 50167, Honolulu, Hawaii, USA \\ ${ }^{2}$ Hawaii Institute of Marine Biology, PO Box 1346, Kane'ohe, Hawaii, USA
}

\begin{abstract}
Coral reefs are highly diverse ecosystems where symbioses play a pivotal role. Corals contain cell-associated microbial aggregates (CAMA), yet little is known about how widespread they are among coral species or the nature of the symbiotic relationship. Using histology, we found CAMA within 24 species of corals from 6 genera from Hawaii, American Samoa, Palmyra, Johnston Atoll, Guam, and Australia. Prevalence (\%) of infection varied among coral genera: Acropora, Porites, and Pocillopora were commonly infected whereas Montipora were not. Acropora from the Western Pacific were significantly more likely to be infected with CAMA than those from the Central Pacific, whereas the reverse was true for Porites. Compared with apparently healthy colonies, tissues from diseased colonies were significantly more likely to have both surface and basal body walls infected. The close association of CAMA with host cells in numerous species of apparently healthy corals and lack of associated cell pathology reveals an intimate agent-host association. Furthermore, CAMA are Gram negative and in some corals may be related to chlamydia or rickettsia. We propose that CAMA in adult corals are facultative secondary symbionts that could play an important ecological role in some dominant coral genera in the Indo-Pacific. CAMA are important in the life histories of other animals, and more work is needed to understand their role in the distribution, evolution, physiology, and immunology of reef corals.
\end{abstract}

KEY WORDS: Coral - Microbes - Facultative . Symbiont · Cell-associated microbial aggregates · Histology

Resale or republication not permitted without written consent of the publisher

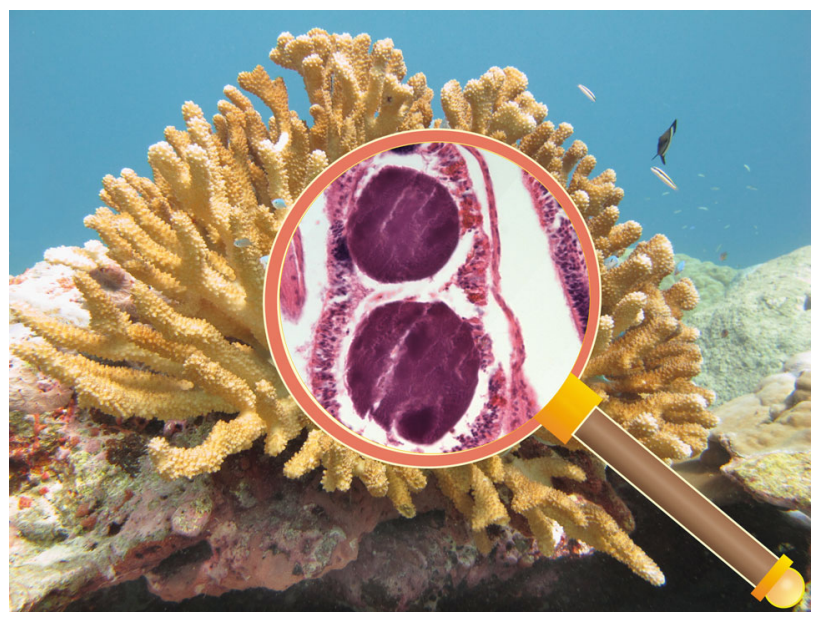

Microscopic bacteria in tissues of coral polyps are important to coral health, ecology, and possibly evolution.

Illustration: Thierry M. Work

\section{INTRODUCTION}

Coral reefs are highly diverse ecosystems where both ecto- and endo-symbioses play a pivotal role. Corals host species-specific mucus-associated bacteria (ectosymbionts) that provide antibiotic defenses for the host (Ritchie 2006), and endolithic bacteria within the skeleton are important for photosynthesis (Fine \& Loya 2002). Corals also have unicellular algae (zooxanthellae) within their cells (endosymbionts) that provide photosynthetically fixed carbon to the host and aid in deposition of the coral skeleton that forms the foundation of coral reefs (Muscatine 1990, Rowan 
1998). The coral-zooxanthellae symbiosis is well studied, and disruption of this symbiosis leads to bleaching (expulsion of zooxanthellae from coral tissues), potential death of the coral, and subsequent ecological disruption to myriad organisms that depend on corals for shelter and food (Glynn 1996, Brown 1997a,b, Hoegh-Guldberg 1999, Coles \& Brown 2003). Cnidaria also have microbial aggregates (bacteria or archaea) found within tissues of 2 species of anemones (McKinstry et al. 1989, Palincsar et al. 1989, Peters \& Yevich 1989), 5 species of reef corals in the Caribbean (Peters et al. 1983, Peters 1984), and 4 species of corals in the Indo-Pacific (Ainsworth et al. 2006, Ainsworth \& Hoegh-Guldberg 2009, Sudek et al. 2012). In situ hybridization studies of microbial aggregates in Acropora and Stylophora from Australia revealed these organisms to be Gammaproteobacteria (Ainsworth et al. 2006), but little is known of their identities in other coral species. Furthermore, nothing is known about how widespread microbial aggregates are among coral species, the nature of the symbiotic relationship, or the role they may have in the health, ecology, or evolution of corals.

The US Geological Survey has a growing archive of histological tissue sections comprising 131 species and 36 genera of healthy and diseased scleractinian corals from across the Indo-Pacific. We examined this archive to determine how widespread cell-associated microbial aggregates (CAMA) are within coral species or genera, the geographic pattern of infections, the type of relationship with host corals, and whether CAMA are associated with coral health.

\section{MATERIALS AND METHODS}

Archived tissue sections stained with hematoxylin and eosin originated from 110 grossly healthy and 386 grossly diseased coral colonies collected between February 1999 and September 2012. The 496 colonies comprised 21 genera and 57 species from Hawaii ( $\mathrm{n}=279)$, American Samoa $(\mathrm{n}=98)$, Palmyra $(\mathrm{n}=58)$, Johnston Atoll $(\mathrm{n}=37)$, Guam $(\mathrm{n}=20)$, and Australia ( $\mathrm{n}=4$ ) (Fig. 1). Tissues were prepared for histology as described in Work \& Aeby (2010). Briefly, coral fragments were fixed in a solution of 1 part zinc formaldehyde (Z-fix, Anatech) and 4 parts seawater, decalcified, trimmed, embedded in paraffin, sectioned at $5 \mu \mathrm{m}$, and stained with hematoxylin and eosin. We examined tissues under light microscopy (generally, a single slide per fragment) and recorded presence/absence of CAMA within surface (surface body wall) or basal (mesenterial filaments,

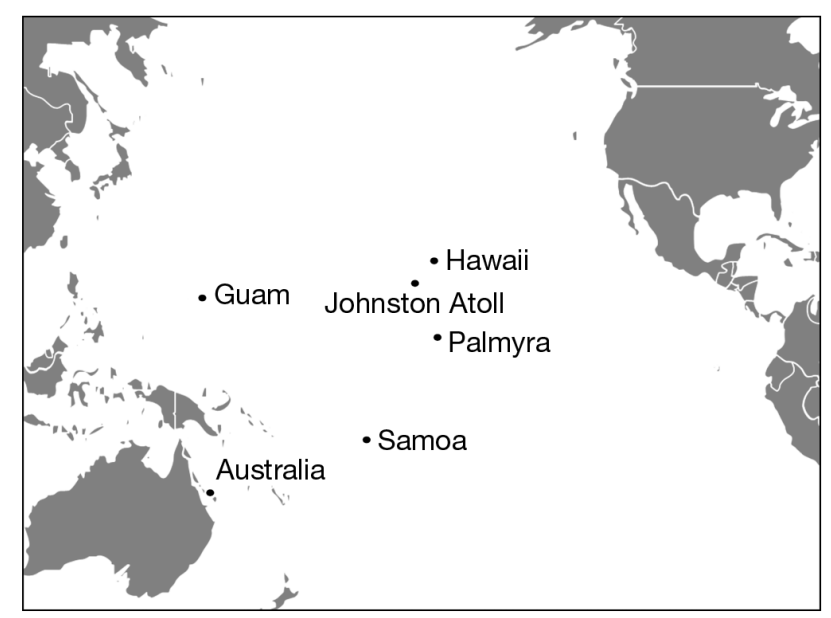

Fig. 1. Regions where corals were sampled for examination of cell-associated microbial aggregates (CAMA)

basal body wall) portions of polyps. When gonads were evident, they were examined for CAMA to investigate the potential for vertical transmission. CAMA were measured with an ocular scale calibrated to a stage micrometer in 1 or 2 dimensions depending on whether they were circular or oblong. Area $\left(\mu \mathrm{m}^{2}\right)$ was calculated using the formula for a circle or ellipse for circular or oblong CAMA, respectively.

To begin to characterize bacteria in CAMA, we used histological stains that routinely identify various groups of bacteria on representative tissue slides. Stains included Gram or Ziehl-Nielsen acid-fast for mycobacteria (Prophet et al. 1992) or Gimenez for chlamydia- or rickettsia-like bacteria (Gimenez 1964). CAMA were examined in more detail in one coral species, Porites compressa, using electron microscopy (EM). For EM, tissues from P. compressa were fixed in Trump's fixative (McDowell \& Trump 1976) made with seawater, rinsed in $0.1 \mathrm{M}$ Sorenson's phosphate buffer, and post-fixed in $2 \%$ osmium tetroxide. Epoxy-embedded tissues were cut to $1 \mathrm{um}$ thickness, stained with toluidine blue, and examined under light microscopy to target areas for EM. Ultrathin sections were stained with uranyl acetate, poststained with lead citrate, and examined with a Zeiss EM 109 electron microscope.

\section{Data analysis}

Health status did not significantly affect prevalence of CAMA $\left(\chi^{2}=0.2126, \mathrm{p}=0.64\right)$; therefore, healthy and diseased corals were pooled for subsequent analysis. For coral genera (Acropora, Montipora, Porites, 
and Pocillopora) and islands (Palmyra, Samoa, Johnston, Hawaii) where we had suitable ( $>20$ per region) sample sizes, we used binomial logistic regression to assess the effects of coral genus, island, or their interaction on presence or absence of CAMA. For those factors or interactions of factors considered significant in the model, post hoc Pearson's chi square was used to assess effects of individual factors or combinations. For Porites where we had adequate samples (Hawaii), we evaluated the effect of species on CAMA prevalence. We also assessed the effect of health versus disease on the number of tissue compartments infected. To compare the size of CAMA among families of corals, we used parametric or non-parametric ANOVA depending on whether data followed a normal distribution as evaluated by the Shapiro-Wilk test. All analyses were conducted using the $\mathrm{R}$ statistical program version 2.13.2 ( $\mathrm{R}$ Development Core Team 2011) with a 0.05 level of significance.

\section{RESULTS}

Of the 57 species of corals comprising 21 genera examined, CAMA were found within 24 species from 6 genera and 5 families. Ten species of Acropora (Acroporidae), 6 species of Porites (Poritidae), 3 species of Pocillopora (Pocilloporidae), 2 species of Platygyra, and 1 species each of Diploastrea, Goniastrea (Faviidae), and Lobophyllia (Mussidae) were infected (Table 1). Coral genus and island were significant factors in explaining presence or absence of CAMA in corals, as were island by genus interactions (Table 2). Coral genus significantly influenced CAMA status $\left(\chi^{2}=\right.$ $118, \mathrm{df}=3, \mathrm{p}<2.2 \times 10^{-16}$ ) with Acropora, Porites, and Pocillopora most likely to be CAMA positive for both healthy and diseased colonies whereas Montipora were uniformly negative (Table 1). For coral genera that were CAMA positive, there were significant regional differences in CAMA status for Acropora
Table 1. Occurrence of cell-associated microbial aggregates (CAMA) within paired lesion and apparently normal fragments from 386 diseased colonies and normal fragments from 110 apparently healthy colonies of various coral species sampled from across the Indo-Pacific. Data show the number of fragments examined histologically for presence of CAMA and the prevalence of infection (\%)

\begin{tabular}{|c|c|c|c|c|c|c|c|}
\hline \multirow[t]{2}{*}{ Genus } & \multirow[t]{2}{*}{ Species } & \multicolumn{4}{|c|}{ Diseased } & \multirow{2}{*}{\multicolumn{2}{|c|}{$\begin{array}{l}\text { Healthy } \\
\text { Normal } \\
\text { (n) }(\%)\end{array}$}} \\
\hline & & $\begin{array}{l}\text { Les } \\
\text { (n) }\end{array}$ & $\begin{array}{l}\text { ion } \\
(\%)\end{array}$ & & $\operatorname{mal}_{(\%)}$ & & \\
\hline \multirow[t]{13}{*}{ Acropora } & A. abrotenoides & 8 & 63 & 8 & 63 & & \\
\hline & A. acuminata & 2 & 100 & 2 & 100 & & \\
\hline & A. austera & 2 & 50 & 2 & 50 & & \\
\hline & A. clathrata & 5 & 60 & 5 & 80 & & \\
\hline & $\begin{array}{l}\text { A. cytherea } \\
\text { A. digitifera }\end{array}$ & $\begin{array}{c}68 \\
2\end{array}$ & $\begin{array}{c}37 \\
0\end{array}$ & $\begin{array}{c}68 \\
2\end{array}$ & $\begin{array}{c}43 \\
100\end{array}$ & 12 & 17 \\
\hline & A. elseyi & & & & & 2 & 0 \\
\hline & A. gemmifera & 1 & 0 & 1 & 0 & 1 & 0 \\
\hline & A. humilis & 1 & 0 & 1 & 100 & & \\
\hline & A. hyacinthus & 9 & 56 & 9 & 78 & & \\
\hline & A. listeri & 1 & 0 & 1 & 0 & & \\
\hline & A. muricata & 9 & 67 & 9 & 67 & & \\
\hline & Acropora sp. & 12 & 58 & 12 & 58 & & \\
\hline & Acropora total & 120 & 45 & 120 & 53 & 15 & 13 \\
\hline \multirow{3}{*}{ Astreopora } & A. listeri & 1 & 0 & 1 & 0 & & \\
\hline & A. myriophthalma & 1 & 0 & 1 & 0 & 1 & 0 \\
\hline & Astreopora total & 2 & 0 & 2 & 0 & 1 & \\
\hline \multirow{2}{*}{$\begin{array}{l}\text { Cyphastrea } \\
\text { Diploastrea }\end{array}$} & C. ocellina & & & & & 1 & 0 \\
\hline & D. heliopora & 2 & 0 & 2 & 50 & & \\
\hline \multirow{5}{*}{$\begin{array}{l}\text { Favia } \\
\text { Fungia }\end{array}$} & F. stelligera & 1 & 0 & 1 & 0 & & \\
\hline & F. concinna & 4 & 0 & 4 & 0 & 1 & 0 \\
\hline & F. scutaria & 2 & 0 & 2 & 0 & 1 & 0 \\
\hline & Fungia sp. & 1 & 0 & 1 & 0 & & \\
\hline & Fungia total & 7 & 0 & 7 & 0 & 2 & 0 \\
\hline \multirow{5}{*}{$\begin{array}{l}\text { Galaxea } \\
\text { Goniastrea }\end{array}$} & Galaxea sp. & & & & & 1 & 0 \\
\hline & G. edwardsi & 5 & 0 & 5 & 0 & & \\
\hline & G. retiformis & 1 & 0 & 1 & 0 & & \\
\hline & Goniastrea sp. & 1 & 0 & 1 & 100 & & \\
\hline & Goniastrea total & 7 & 0 & 7 & 14 & & \\
\hline \multirow{7}{*}{$\begin{array}{l}\text { Hydnophora } \\
\text { Leptastrea } \\
\text { Leptoria } \\
\text { Leptoseris } \\
\text { Lobophyllia }\end{array}$} & H. microconos & 1 & 0 & 1 & 0 & & \\
\hline & L. purpurea & & & & & 1 & 0 \\
\hline & L. phrygia & 1 & 0 & 1 & 0 & & \\
\hline & Leptoseris sp. & & & & & 4 & 0 \\
\hline & L. hemprichii & & & & & 1 & 0 \\
\hline & Lobophyllia sp. & 2 & 50 & 2 & 0 & & \\
\hline & Lobophyllia total & 2 & 50 & 2 & 0 & 1 & 0 \\
\hline \multirow{10}{*}{$\begin{array}{l}\text { Merulina } \\
\text { Montipora }\end{array}$} & M. scabricula & 1 & 0 & 1 & 0 & & \\
\hline & M. aequituberculata & 3 & 0 & 3 & 0 & & \\
\hline & M. capitata & 115 & 0 & 115 & 0 & 12 & 0 \\
\hline & M. dilitata & 1 & 0 & 1 & 0 & & \\
\hline & M. efflorescens & 2 & 0 & 2 & 0 & & \\
\hline & M. flabellata & 1 & 0 & 1 & 0 & 1 & 0 \\
\hline & M. foveolata & 1 & 0 & 1 & 0 & & \\
\hline & M. patula & 24 & 0 & 24 & 0 & 3 & 0 \\
\hline & Montipora sp. & 6 & 0 & 6 & 0 & & \\
\hline & Montipora total & 153 & 0 & 153 & 0 & 16 & 0 \\
\hline Pavona & P. frondifera & & & & & 1 & 0 \\
\hline & P. varians & 1 & 0 & 1 & 0 & 1 & 0 \\
\hline & Pavona total & 1 & 0 & 1 & 0 & 2 & 0 \\
\hline Pectinia & P. lactuca & & & & & 1 & 0 \\
\hline Platygyra & P. daedalea & 2 & 100 & 2 & 100 & & \\
\hline & Platygyra sp. & 1 & 0 & 1 & 100 & & \\
\hline & Platygyra total & 4 & 50 & 3 & 100 & & \\
\hline Pocillopora & P. damicornis & & & & & 2 & 0 \\
\hline & P. eydouxi & 4 & 50 & 4 & 50 & 3 & 0 \\
\hline & P. meandrina & 11 & 82 & 11 & 82 & 2 & 50 \\
\hline & Pocillopora sp. & & & 1 & 0 & 8 & 0 \\
\hline & P. verrucosa & 1 & 100 & 1 & 0 & & \\
\hline & Pocillopora total & 16 & 75 & 16 & 69 & 15 & 7 \\
\hline Porites & P. compressa & 14 & 64 & 14 & 71 & 35 & 74 \\
\hline & P. cylindrica & 11 & 82 & 11 & 91 & & \\
\hline & P. evermanni & 7 & 14 & 7 & 14 & 5 & 0 \\
\hline & P. lobata & 14 & 57 & 14 & 71 & 8 & 63 \\
\hline & P. rus & 6 & 17 & 6 & 17 & 1 & 100 \\
\hline & Porites sp. & 12 & 25 & 12 & 17 & 1 & 0 \\
\hline & Porites total & 64 & 48 & 64 & 53 & 50 & 64 \\
\hline Turbinaria & T. reniformis & 5 & 0 & 5 & 0 & & \\
\hline
\end{tabular}


Table 2. Logistic regression of cell-associated microbial aggregate status (CAMA) (positive/negative) on explanatory factors: genus (Acropora, Porites, Pocillopora, Montipora) and island (Samoa, Palmyra, Johnston, Hawaii). A p < 0.05 indicates significant contributions to model. Australia and Guam were not included in the regression analysis due to inadequate sample sizes

\begin{tabular}{|lccccc|}
\hline Factor & df & Deviance & Residual df & Residual dev. & $\mathrm{p}$ \\
\hline Null & & & 14 & 263.341 & \\
Genus & 3 & 161.611 & 11 & 101.73 & $<2.2 \times 10^{-16}$ \\
Island & 3 & 55.124 & 8 & 46.606 & $6.46 \times 10^{-12}$ \\
Genus $\times$ Island & 8 & 46.606 & 0 & 0 & $1.82 \times 10^{-7}$ \\
\hline
\end{tabular}

$\left(\chi^{2}=58, \mathrm{df}=3, \mathrm{p}=1.3 \times 10^{-12}\right)$, Pocillopora $\left(\chi^{2}=9\right.$, $\mathrm{df}=3, \mathrm{p}=0.02)$, and Porites $\left(\chi^{2}=10, \mathrm{df}=2, \mathrm{p}=0.006\right.$; Table 3). In Acropora, there was a higher proportion of samples infected with CAMA in the Western Pacific, and this regional pattern was especially prominent in A. cytherea (Fig. 2). Where sample sizes were adequate, we also looked at species differences in infection rate within genera. For Porites in Hawaii, $P$. compressa $(\mathrm{n}=49)$ and P. lobata $(\mathrm{n}=21)$ had the highest rates of infection (73.5 and $71.4 \%$, respectively) compared with P. rus $(\mathrm{n}=6,16.7 \%)$ and $P$. evermanni $\left(\mathrm{n}=11,9.1 \% ; \chi^{2}=24, \mathrm{df}=3, \mathrm{p}=1.1 \times 10^{-5}\right)$.

Within coral tissues, CAMA were observed to be round to oblong within multiple tissue compartments, including all compartments of surface and basal body walls, with no evident host response (Fig. 3). With hematoxylin and eosin, CAMA stained basophilic (blue) or eosinophilic (pink) with no evident staining pattern for genera or family of corals. It was difficult to confirm with light microscopy whether CAMA were intra- or extra-cellular; however, on ultrastructure, CAMA in Porites compressa sometimes appeared to be surrounded by cell membranes, suggesting that they were within coral cells (Fig. 3M-O). A significant difference in size of CAMA was found among 4 families of corals examined (Kruskal-Wallis, $\mathrm{df}=3, \chi^{2}=14, \mathrm{p}=0.002$ ). Post hoc pairwise comparisons showed that CAMA from Faviidae samples were significantly larger than those from Pocilloporidae (critical difference $=53, p<0.05$ ) and Poritidae (critical difference $=43, \mathrm{p}<0.05$ ), but no significant differences in size were found among other pairs (Table 4). Health status affected the number of tissue compartments infected with CAMA, with grossly normal fragments from diseased colonies significantly more likely to have both surface (epidermis, gastrodermis) and basal (mesenterial filaments, gastrodermis, calicodermis) body walls infected $\left(\chi^{2}=7, \mathrm{df}=2, \mathrm{p}=0.03\right)$ compared with fragments from healthy colonies that had CAMA predominantly in surface body walls only (Table 5).

No CAMA were found in oocytes or spermaries from 41 Acropora, 7 Porites, or 2 Pocillopora colonies (Table 6). CAMA from 6 species of Acropora ( $A$. abrotenoides, A. acuminata, A. austera, A. cytherea, A. hyacinthus, A. muricata), 5 species of Porites ( $P$. compressa, $P$. cylindrical, $P$. evermanni, $P$. lobata, $P$. rus), 2 species of Pocillopora (P. eydouxi, P. meandrina) and 1 each Goniastrea sp. and Platygyra sp. stained negative for mycobacteria with Ziehl-Nielsen acid-fast and were Gram negative; however, $A$. acuminata stained positive for chlamydia- or rickettsia-like bacteria with Gimenez (Fig. 3).

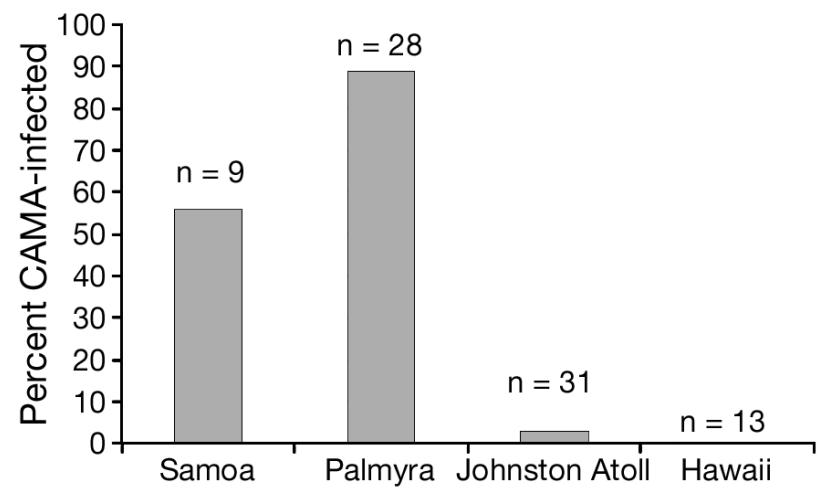

Fig. 2. Regional pattern of cell-associated microbial aggregate (CAMA) infection in samples from colonies of Acropora cytherea. Sample sizes are indicated for each region surveyed

Table 3. Regional differences in occurrence of cell-associated microbial aggregates (CAMA) in 3 coral genera. Data reflect percent of samples examined that were CAMA infected partitioned by region, island and genus

\begin{tabular}{|c|c|c|c|c|c|c|c|c|c|c|c|c|}
\hline \multirow[t]{3}{*}{ Genus } & \multicolumn{8}{|c|}{ - Western Pacific - } & \multicolumn{4}{|c|}{ Central Pacific } \\
\hline & \multicolumn{2}{|c|}{ Australia } & \multicolumn{2}{|c|}{ Guam } & \multicolumn{2}{|c|}{ Samoa } & \multicolumn{2}{|c|}{ Palmyra } & \multicolumn{2}{|c|}{ Johnston } & \multicolumn{2}{|c|}{ Hawaii } \\
\hline & $\mathrm{n}$ & $\%$ & $\mathrm{n}$ & $\%$ & $\mathrm{n}$ & $\%$ & $\mathrm{n}$ & $\%$ & $\mathrm{n}$ & $\%$ & $\mathrm{n}$ & $\%$ \\
\hline Acropora & 1 & 0 & 7 & 57.1 & 45 & 64.4 & 36 & 86.1 & 32 & 3.1 & 14 & 0 \\
\hline Pocillopora & 0 & 0 & 0 & 0 & 5 & 20 & 4 & 100 & 1 & 100 & 21 & 28.6 \\
\hline Porites & 0 & 0 & 13 & 92.3 & 13 & 15.4 & 1 & 0 & 0 & 0 & 87 & 59.8 \\
\hline
\end{tabular}



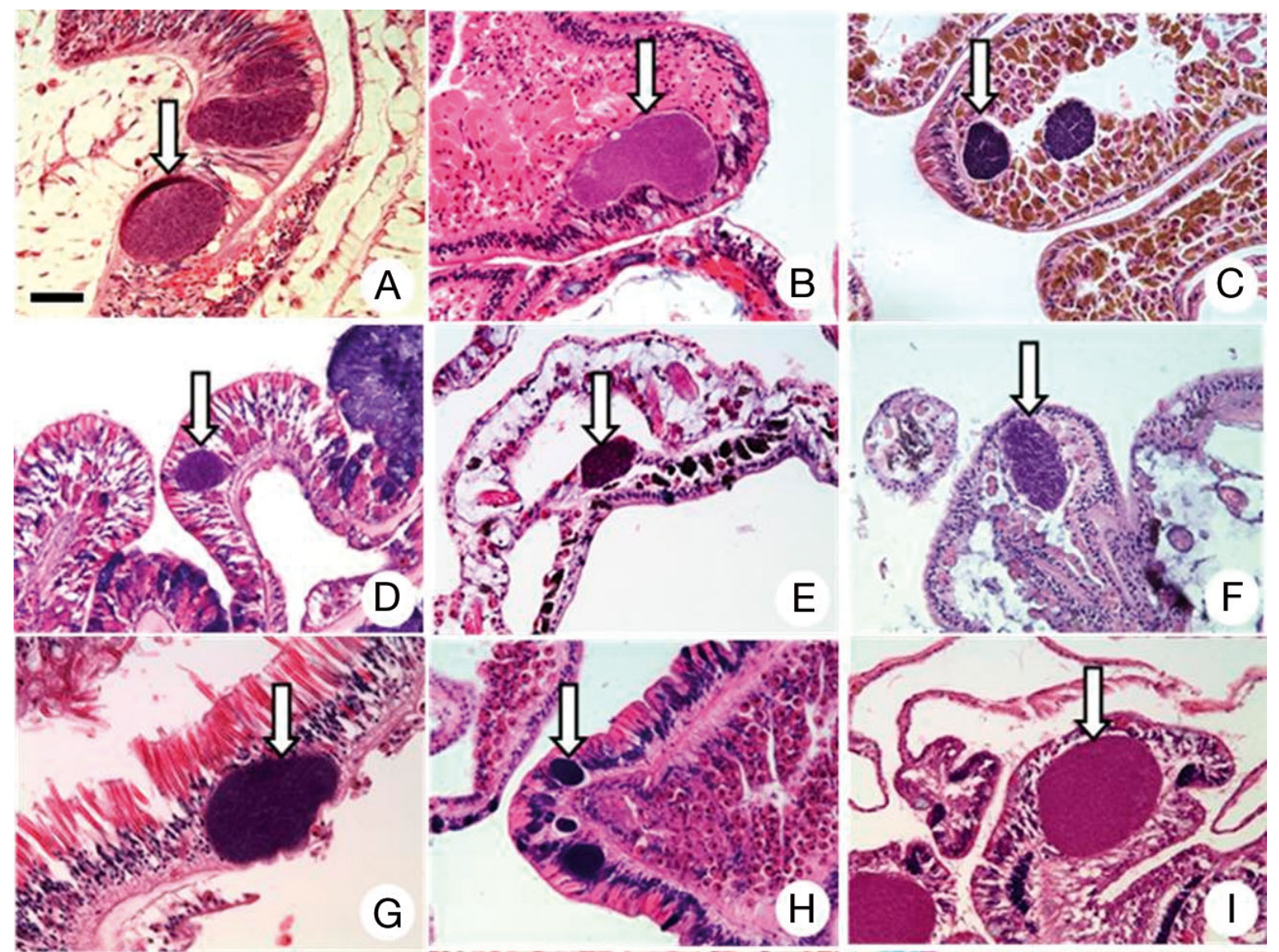

G
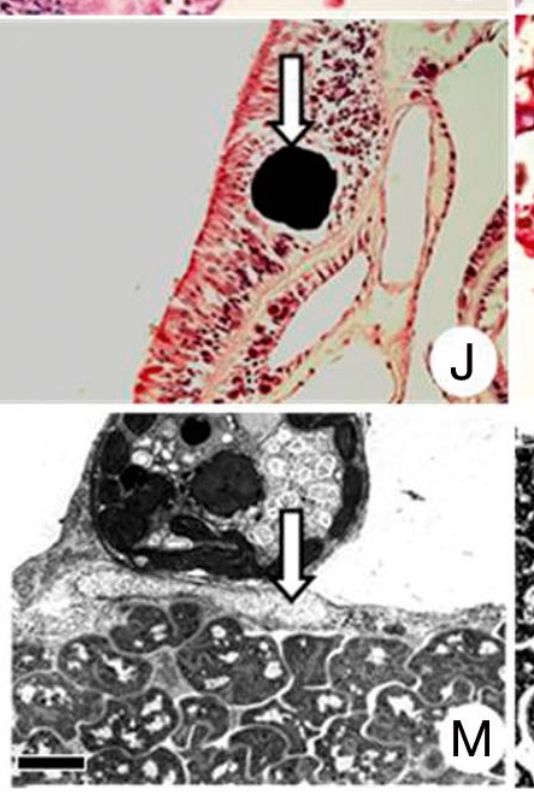

(3) (2)
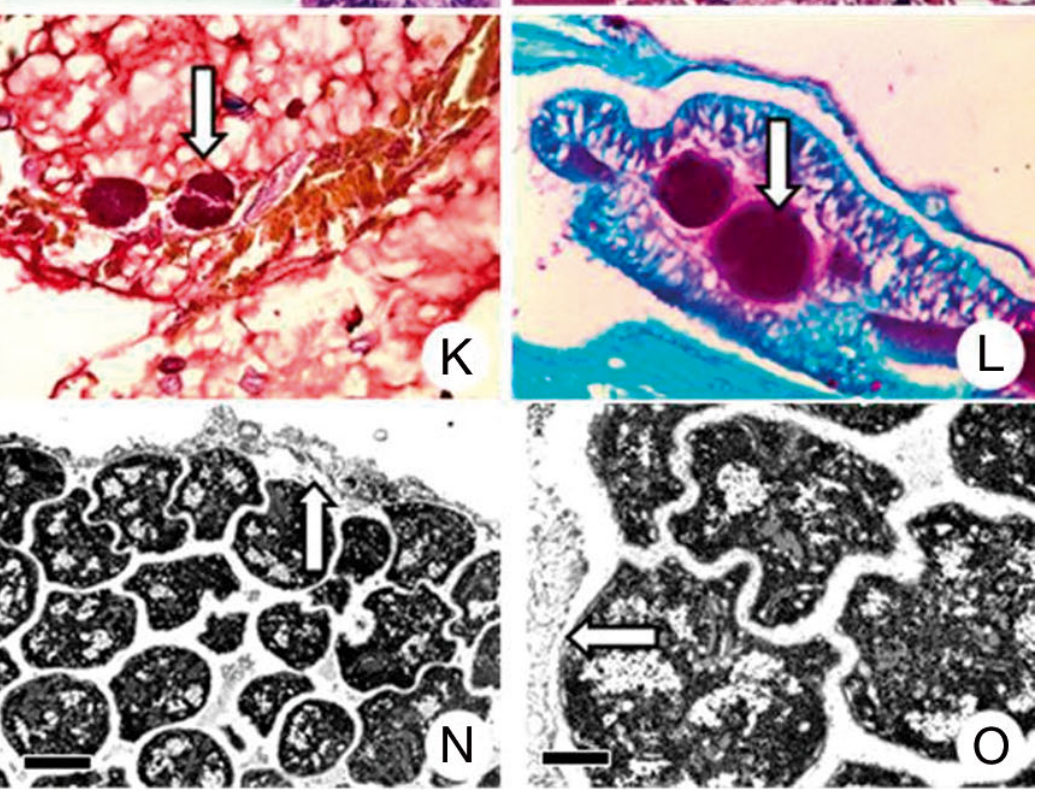

Fig. 3. Cell-associated microbial aggregates (CAMA) in corals. (A-J) Hematoxylin and eosin, (K) Gram, (L) Gimenez stain, $(\mathrm{M}, \mathrm{N}, \mathrm{O})$ electron micrographs. (A-L) Scale bar $=20 \mu \mathrm{m}$; arrows in all panels point to CAMA. (A) Platygyra daedalea, (B) Diploastrea heliopora, (C) Goniastrea sp., (D) Pocillopora meandrina, (E) Porites evermanni, (F) Porites rus, (G) Lobophyllia sp., (H) Acropora clathrata, (I) Acropora acuminata, (J) A. hyacinthus, (K) Porites compressa, (L) Acropora muricata. (M) Electron micrograph of CAMA within the gastrodermis of the surface body wall of P. compressa; note the zooxanthella (top) adjacent to CAMA (bottom), displacing and flattening the host-cell nucleus (arrow); scale bar $=2 \mu \mathrm{m}$. (N) CAMA enclosed by what appears to be cell membrane (arrow); scale bar $=1 \mu \mathrm{m}$. (O) Apparently extracellular CAMA adjacent to connective tissue (arrow); scale 
Table 4. Mean, SD, range, and sample size (n) of measurement $\left(\mu^{2}\right)$ of cell-associated microbial aggregates (CAMA) in various species of corals partitioned by family

\begin{tabular}{|llcccc|}
\hline \multirow{2}{*}{ Family } & Species & Mean & SD & Range & $\mathrm{n}$ \\
\hline Acroporidae & Acropora abrotenoides & 506 & 390 & $59-1571$ & 20 \\
& Acropora acuminata & 1329 & 645 & $471-2945$ & 20 \\
& Acropora austera & 3241 & 1911 & $393-7461$ & 20 \\
& Acropora clathrata & 504 & 504 & $20-2376$ & 20 \\
& Acropora cytherea & 978 & 751 & $79-3063$ & 20 \\
& Acropora digitifera & 785 & 458 & $118-1414$ & 8 \\
& Acropora humilis & 1168 & 697 & $471-1865$ & 2 \\
& Acropora hyacinthus & 644 & 406 & $79-1767$ & 20 \\
& Acropora muricata & 866 & 546 & $177-2376$ & 20 \\
& Acroporidae total & 1133 & 1231 & $20-7461$ & 150 \\
Faviidae & Diploastrea heliopora & 6048 & 0 & 6048 & 1 \\
& Goniastrea sp. & 697 & 315 & $314-1414$ & 20 \\
& Platygyra daedalea & 2662 & 2440 & $236-10210$ & 20 \\
& Faviidae total & 1786 & 2111 & $236-10210$ & 41 \\
Pocilloporidae & Pocillopora eydouxi & 484 & 285 & $177-1100$ & 9 \\
& Pocillopora meandrina & 624 & 300 & $177-1257$ & 20 \\
& Pocilloporidae total & 581 & 308 & $177-1257$ & 29 \\
Poritidae & Porites compressa & 624 & 247 & $177-1100$ & 20 \\
& Porites cylindrica & 384 & 209 & $177-962$ & 20 \\
& Porites evermanni & 674 & 273 & $471-1060$ & 3 \\
& Porites lobata & 925 & 463 & $314-1963$ & 20 \\
& Porites rus & 1158 & 270 & $785-1414$ & 3 \\
& Poritidae total & 669 & 402 & $177-1963$ & 66 \\
\hline
\end{tabular}

Table 5. Location of cell-associated microbial aggregates (CAMA) within coral tissues for apparently normal fragments of healthy versus diseased colonies. Data show the number of samples that had CAMA within each tissue compartment

\begin{tabular}{|lcc|}
\hline Compartment infected & Diseased & Healthy \\
\hline Surface body wall only & 87 & 94 \\
Basal body wall only & 6 & 6 \\
Surface and basal body wall & 7 & 0 \\
\hline
\end{tabular}

Table 6. Sample size by genus of gonads examined microscopically for cell-associated microbial aggregates (CAMA) in healthy or diseased colonies. Both indicates presence of oocytes and spermaries within the sample; female is oocytes only, male is spermaries only. CAMA were not found in any of the gonads examined

\begin{tabular}{|lrccr|}
\hline Genus & Both & Female & Male & Total \\
\hline Acropora & 13 & 28 & 0 & 41 \\
Diploastrea & 0 & 1 & 0 & 1 \\
Hydnophora & 1 & 0 & 0 & 1 \\
Leptoseris & 0 & 2 & 0 & 2 \\
Lobophyllia & 0 & 1 & 0 & 1 \\
Pavona & 0 & 1 & 0 & 1 \\
Platygyra & 0 & 1 & 0 & 1 \\
Pocillopora & 1 & 0 & 1 & 2 \\
Porites & 0 & 4 & 3 & 7 \\
Turbinaria & 0 & 1 & 0 & 1 \\
\hline
\end{tabular}

\section{DISCUSSION}

This is the first report of widespread CAMA infections in IndoPacific corals, with only 4 Indo-Pacific coral species known to be CAMAinfected prior to this report. Along with their close association with host cells, their presence in healthy colonies, and the lack of evident cell pathology at the gross and ultrastructural levels, this indicates an intimate and widespread agent-host association in adult colonies. Endosymbionts can be either obligate primary or facultative secondary associations (Moya et al. 2008). Our study showed that CAMA were not found in all species of coral, nor in all regions in which affected species occurred, indicating that CAMA are not necessary for host survival or reproduction for established coral colonies. This suggests that coral-CAMA symbioses are facultative secondary relationships for adult colonies of numerous select coral species.

Results from light microscopy showed that CAMA within coral tissues were similar in size, shape, and staining properties compared with studies of other Cnidaria; they were round to oblong and morphologically similar to those observed in anemones (McKinstry et al. 1989, Palincsar et al. 1989, Peters \& Yevich 1989) and corals (Peters et al. 1983, Peters 1984, Ainsworth et al. 2006, Ainsworth \& HoeghGuldberg 2009, Sudek et al. 2012). With hematoxylin and eosin, CAMA in our study stained both pink and purple depending on the species of coral examined. Hematoxylin and eosin generally stain DNA as purple and proteins as pink (Prophet et al. 1992), so it was unexpected that CAMA stained pink. However, CAMA in other studies have stained purple (Peters et al. 1983) as well as pink (Sudek et al. 2012). Perhaps the variability in staining characteristics seen in CAMA is reflective of varying degrees of protein or DNA production or local tissue $\mathrm{pH}$ conditions, which can affect staining characteristics, but additional tools such as immunohistochemistry or in situ hybridization would be necessary to determine this. The diameter size range of CAMA in Acropora in our study (5-100 $\mu \mathrm{m})$ was within that reported for this genus from the Caribbean $(40 \mu \mathrm{m})$ and the Pacific $(7-80 \mu \mathrm{m})$ (Peters et al. 1983, Ainsworth \& Hoegh-Guldberg 
2009). Likewise, CAMA in Porites compressa from Hawaii ranged from 170 to $1914 \mu^{2}$ (Sudek et al. 2012), similar to what we observed (177-1100 $\left.\mu^{2}\right)$. Interestingly, we found a great deal of variation in size of CAMA among families of corals, with those of Faviidae being particularly large. To our knowledge, this is the first time such systematic variations have been documented, and this phenomenon merits further investigation. In all of the coral species we examined, CAMA stained Gram negative, as did those in all of the aforementioned studies. All CAMA seen here also stained negative with acid-fast stains, similar to CAMA found in Hydra (Thorington et al. 1979).

EM showed that prokaryotes within CAMA had characteristic a size (1-4 $\mu \mathrm{m}$ diameter) and shape similar to that observed in Acropora (Peters et al. 1983, Ainsworth \& Hoegh-Guldberg 2009) and Aiptasia (Palincsar et al. 1989), with cells packed closely together. With light microscopy, it was difficult to determine whether CAMA were intra- or extra-cellular. In the one species of coral examined ultrastructurally (Porites compressa), CAMA were sometimes surrounded by what appeared to be a cell membrane, indicating an intracellular location, and other times appeared to be extracellular. In Aiptasia, small CAMA are intracellular in epidermal cells (McKinstry et al. 1989) but extracellular when larger (Palincsar et al. 1989), whereas they are exclusively intracellular in gastrodermal cells in Hydra (Margulis et al. 1978). Clearly, additional work at the ultrastructural level is needed to sort out what cell types, if any, CAMA infect in scleractinian corals.

CAMA were found infecting numerous species of corals throughout the Indo-Pacific, but of 21 genera examined, infections were found in only 6, with Acropora, Porites, and Pocillopora predominating. Sample sizes were small in some coral genera that were CAMA negative, precluding generalizations, but CAMA were absent in Montipora, which had robust sample sizes across regions. Genera- and speciesspecific differences in the presence of the coral-CAMA symbiosis raises many interesting questions as to why some species or genera have developed this relationship but others have not. In order for a symbiosis to become fixed in a host population, you would expect there to be a selective advantage favoring the maintenance of the association (Margulis 1993). Interestingly, 3 of the 6 genera that commonly host CAMA (Acropora, Porites, and Pocillopora) are some of the most numerically dominant corals on reefs in the IndoPacific (Bellwood \& Hughes 2001). Further work is clearly needed to understand the evolution and ecology of the coral-CAMA endosymbiotic relationship.
We also found regional differences within CAMAinfected coral genera. For example, we found a $92 \%$ infection rate in Porites in Guam compared with a $15 \%$ infection rate in colonies from American Samoa even though the sample sizes were equal. Speciesspecific differences in infection rate do occur within genera, and some of the regional differences may be due to sampling effort. However, we also found regional differences within a single species (Acropora cytherea). Perhaps there are differences in modes of transmission (vertical vs. horizontal) of CABA, depending on genera or species, that affect dispersal ability across geographic areas, and/or the coralCABA endosymbioses might be favored in some regions but not others. The effects of infection by other facultative symbionts can be mediated by the ecological context of the host organism (Oliver et al. 2010), and explaining regional trends in corals will require further study.

In some insect-bacterial symbioses, the bacteria have been shown to influence their hosts' ability to defend themselves again natural enemies (Oliver et al. 2008). Facultative CAMA in pea aphids confer resistance to parasitoid attack by causing high mortality of developing parasitoid larvae in host aphids (Oliver et al. 2003). The role that CAMA may play in the health of corals is unknown, but healthy tissue from diseased colonies had more tissue compartments infected with CAMA than tissue from healthy colonies. This opens up the possibility that corals could be upregulating factors that promote CAMA in response to stressors. Fitness benefits from the symbioses could vary among host genera and depend on the ecological context. However, the widespread distribution of the symbioses within all of these genera and the lack of cell pathology linked to CAMA would argue in favor of a selective advantage to host fitness maintaining the association in adult coral populations. Although the mechanisms by which CAMA may modulate coral fitness are unclear, in insects, bacterial endosymbionts provide essential nutrients and resistance to heat (Moran \& Telang 1998), and defense against parasitoids (Oliver et al. 2003) fungi (Haine 2008), and viruses (Teixeira et al. 2008). Finally, although the identity of most CAMA in corals remains unknown, the presence of chlamydia- or rickettsia-like bacteria in Acropora acuminata suggests a degree of heterogeneity in CAMA that merits further exploration.

We saw no evidence of CAMA in the gonads of corals; however, our methods were not sensitive enough to detect single bacterial cells, so we cannot categorically eliminate the possibility of vertical trans- 
mission. Nevertheless, the regional differences in the prevalence of CAMA infections in adult Acropora cytherea suggest an absence of vertical transmission, as larvae do not appear to be transporting their CAMA symbionts with them into new regions. $A$. cytherea from Palmyra and American Samoa contained CAMA, yet few colonies in Johnston Atoll and no colonies in Hawaii were infected. An alternative hypothesis is that initial $A$. cytherea colonizers into Johnston Atoll or Hawaii may have contained CAMA, but the association was lost through time. It is likely that a variety of transmission mechanisms for CAMA exist depending on the coral species. For example, there was no evidence of vertical transmission of bacteria in the gonads or larval stages of 7 coral species in the Caribbean (Sharp et al. 2010); however, internalized bacterial cells were seen in Porites asteroides larvae, suggesting vertical transmission (Sharp et al. 2012). Similarly, symbiotic zooxanthellae within scleractinian corals are transmitted both vertically (Hirose et al. 2000) and horizontally (van Oppen 2004), depending on the coral species.

In summary, we present the first wide-scale survey of the presence of CAMA in corals across the IndoPacific. We suggest that CAMA are geographically widespread, facultative secondary endosymbionts of select coral genera, and it is unlikely this would have been discovered without historical tissue archives; such archives have helped elucidate ecological processes in corals elsewhere (Hoeksema et al. 2011). These findings open a host of questions that should provide fertile ground for further research, including the identity of CAMA, the cell types they infect, and their role in coral distribution, evolution, physiology, and immunology.

Acknowledgements. Mention of products or trade names does not imply endorsement by the US Government. We are thankful to Dr. Douglas Fenner for assistance in confirming identify of some coral species. Geraldine Takata kindly performed the electron microscopy.

\section{LITERATURE CITED}

- Ainsworth TD, Hoegh-Guldberg O (2009) Bacterial communities closely associated with coral tissues vary under experimental and natural reef conditions and thermal stress. Aquat Biol 4:289-296

> Ainsworth TD, Fine M, Blackall LL, Hoegh-Guldberg O (2006) Fluorescence in-situ hybridization and spectral imaging of coral-associated bacterial communities. Appl Environ Microbiol 72:3016-3020

Bellwood DR, Hughes TP (2001) Regional-scale assembly rules and biodiversity of coral reefs. Science 292: 1532-1535
Brown BE (1997a) Coral bleaching: causes and consequences. Coral Reefs 16:S129-S138

Brown BE (1997b) Disturbances to reefs in recent times. In: Birkeland C (ed) Life and death of coral reefs. Springer, Berlin, p 1-24

> Coles SL, Brown BE (2003) Coral bleaching - capacity for acclimatization and adaptation. Adv Mar Biol 46:183-223

Fine M, Loya Y (2002) Endolithic algae - an alternative source of energy during coral bleaching. Proc Biol Sci 269:1205-1210

Gimenez DF (1964) Staining rickettsiae in yolk sac culture. Stain Technol 39:135-140

> Glynn PW (1996) Coral reef bleaching: facts, hypotheses and implications. Glob Change Biol 2:495-509

Haine ER (2008) Symbiont-mediated protection. Proc Biol Sci 275:353-361

Hirose M, Kinzie RA III, Hidaka M (2000) Early development of zooxanthella-containing eggs of the corals Pocillopora verrucosa and $P$. eydouxi with special reference to the distribution of zooxanthellae. Biol Bull 199:68-75

Hoegh-Guldberg O (1999) Climate change, coral bleaching and the future of the world's coral reefs. Mar Freshw Res 50:839-866

Hoeksema BW, van der Land J, van der Meij SET, van Ofwegen LP, Reijnen BT, van Soest RBM, de Voogd NJ (2011) Unforeseen importance of historical collections as baselines to determine biotic change of coral reefs: the Saba Bank case. Mar Ecol 32:135-141

Margulis L (1993) Origins of species: acquired genomes and individuality. Biosystems 31:121-125

> Margulis L, Thorington G, Berger B, Stolz J (1978) Endosymbiotic bacteria associated with the intracellular green algae of Hydra viridis. Curr Microbiol 1:227-232

McDowell EM, Trump BF (1976) Histological fixatives for diagnostic light and electron microscopy. Arch Pathol Lab Med 100:405-414

McKinstry MJ, Chapman GB, Spoon DM, Peters EC (1989) The occurrence of bacterial colonies in the epidermis of the tentacles of the sea anemone Aiptasia pallida (Anthozoa: Actinaria). Trans Am Microsc Soc 108:239-244

> Moran NA, Telang A (1998) Bacteriocyte-associated symbionts. Bioscience 48:295-304

> Moya A, Peretó J, Gil R, Latorre A (2008) Learning how to live together: genomic insights into prokaryote-animal symbioses. Nat Rev Genet 9:218-229

Muscatine L (1990) The role of symbiotic algae in carbon and energy flux in reef corals. In: Dubinsky Z (ed) Ecosystems of the world, Vol 25. Coral reefs. Elsevier Science Publishing, Amsterdam, p 75-87

- Oliver KM, Russell JA, Moran NA, Hunter MS (2003) Facultative bacterial symbionts in aphids confer resistance to parasitic wasps. Proc Natl Acad Sci USA 100:1803-1807

Oliver KM, Campos J, Moran NA, Hunter MS (2008) Population dynamics of defensive symbionts in aphids. Proc Biol Sci 275:293-299

> Oliver KM, Degnan PH, Burke GR, Moran NA (2010) Facultative symbionts in aphids and the horizontal transfer of ecologically important traits. Annu Rev Entomol 55: $247-266$

> Palincsar EE, Jones WR, Palincsar JS, Glogowski MA, Mastro JL (1989) Bacterial aggregates within the epidermis of the sea anemone Aiptasia pallida. Biol Bull 177:130-140

Peters EC (1984) A survey of cellular reactions to environmental stress and disease in Caribbean scleractinian corals. Helgol Meeresunters 37:113-137

> Peters EC, Yevich PP (1989) Histopathology of Ceriantheop- 
sis americanus (Cnidaria: Cenantharia) exposed to Black Rock Harbor dredge spoils in Long Island Sound. Dis Aquat Org 7:137-148

Peters EC, Oprandy JJ, Yevich PP (1983) Possible causal agent of 'white band disease' in Caribbean acroporid corals. J Invertebr Pathol 41:394-396

Prophet EB, Mills B, Arrington JB, Sobin LH (1992) Laboratory methods in histotechnology. Armed Forces Institute of Pathology, Washington, DC

R Development Core Team (2011) R: a language and environment for statistical computing. R Foundation for Statistical Computing, Vienna

Ritchie KB (2006) Regulation of microbial populations by coral surface mucus and mucus-associated bacteria. Mar Ecol Prog Ser 322:1-14

Rowan R (1998) Diversity and ecology of zooxanthellae on coral reefs. J Phycol 34:407-417

Sharp KH, Ritchie KB, Schupp PJ, Ritson-Williams R, Paul VJ (2010) Bacterial acquisition in juveniles of several broadcast spawning coral species. PLoS ONE 5:e10898

Editorial responsibility: Charles Birkeland,

Honolulu, Hawaii, USA
Sharp KH, Distel D, Paul VJ (2012) Diversity and dynamics of bacterial communities in early life stages of the Caribbean coral Porites astreoides. ISME J 6:790-801

Sudek M, Work TM, Aeby GS, Davy SK (2012) Histological observations in the Hawaiian reef coral, Porites compressa, affected by Porites bleaching with tissue loss. J Invertebr Pathol 111:121-125

Teixeira L, Ivaro-Ferreira A, Ashburner M (2008) The bacterial symbiont Wolbachia induces resistance to RNA viral infections in Drosophila melanogaster. PLoS Biol 6: e1000002

Thorington G, Berger B, Margulis L (1979) Transmission of symbionts through the sexual cycle of Hydra viridis. i. Observations on living organism. Trans Am Microsc Soc 98:401-403

van Oppen MJH (2004) Mode of zooxanthella transmission does not affect zooxanthella diversity in acroporid corals. Mar Biol 144:1-7

Work TM, Aeby GS (2010) Wound repair in Montipora capitata. J Invertebr Pathol 105:116-119

Submitted: October 2, 2013; Accepted: December 13, 2013 Proofs received from author(s): February 13, 2014 